$\left[\begin{array}{lll}\text { Jpn } & \text { J. Hosp. Pharm. } \\ \hline 21(5) & \text { 般 } & \text { 論 } \\ 296-403 & (1995)\end{array}\right]$

\title{
各種テオフィリン徐放性製剤の異なった保存環境下における安定性†1
}

\author{
岩田政則，中村泰子，一澤正之，城武舁一 \\ 横浜市立大学医学部附属病院薬剤部†2
}

\section{Stability of Sustained-Release Theophylline Preparations under Different Storage Conditions $\dagger^{-1}$}

\author{
MASANORI IWATA, YASUKo NAKAMURA, MASAyUKi ICHISAWA, \\ and SHOICHI SHIROTAKE \\ Department of Pharmacy, Yokohama City University Hospital†²
}

$\left(\begin{array}{l}\text { Received March 13, 1955) } \\ \text { Accepted June 8, 1995 }\end{array}\right.$

The pharmaceutical characteristics of Theodur(TD), Theolong (TL) and Slo-bid(SB) as commercial theophylline sustained-release preparations were investigated. According to the experimental design under the conditions consisted of temperature $\left(20-80^{\circ} \mathrm{C}\right)$ and relative humidity (40-80\%), these preparations were kept under five kinds of storage conditions for 14 days. The contents of theophylline in each of the preparations were stable. When preparations were kept at $80^{\circ}-70 \%$, the hardness of TD reduced rapidly with the passage of time. After keeping the preparation in $80^{\circ}$ for 14 days, the release of theophylline from TD was accelerated. On the other hand, release of theophylline from TL was delayed with increasing temperature. SB was not suffered from temperature and relative humidity on the release of theophylline.

In the cases of TD and TL, the effect of the structural change on the release profiles was suggested by surface condition observation using a scanning electron microscope. Response variables were predicted by multiple regression analysis and simulation technique. The results reveald that each sustained release preparation designed by our pharmaceutical technique have different characteristics and produced a different effect on the drug release profiles according to the storage conditions.

Keywords_- stability, thephylline, sustained-release preparation, drug release property, storage condition, temperature, relative humidity

\author{
緒言 \\ キサンチン誘導体は，19世紀半ばに喘息の症状 \\ 軽減作用が発見されて以来, 喘息の薬物療法の中 \\ $\dagger^{1}$ 本報の一部は, 第 3 回日本病院薬学会(東京, 1993 \\ 年 7 月）で発表. \\ †2 神奈川県横浜市金沢区福浦 3-9; 3-9, Fukuura, \\ Kanazawa-ku, Yokohama-shi, 236, Japan
}

核的役割をはたし，治療薬としての有効性が確立 された1)。テオフィリンは血中濃度でのいわゆる 有効治療域が龹く，中毒域が近接して抢り ${ }^{2)}$, そ の副作用には不整脈、けいれん等があげられ，重 篤な場合も少なくない.このような状況のもと で，テオフィリンの経口投与製剤としては，血中 濃度を一定に維持することを目的とした徐放性製 剤がひろく用いられている. テォフィリン徐放性 
製剂は，それぞれ種々の製剤技術が導入された製 剤であり，それゆ洛特性に差が存在すること が推測される、したがって，薬凨師による各製剂 の有効性や安全性の確保には，その特性を認識 し, 種々の保存条件がもたらす製剂特性への影響 を捉えることが重要である.

そこで， 3 種のテオフィリン徐放性製剤につい て，その製剤特性を比較し，複合実験計画 ${ }^{3)}$ を適 用して, 温度, 湿度を同時に変化させた保存条件 での製剤特性に与える影響および製剤の形態変化 について薬剤学的検討を行った.

\section{実 験 の 部}

\section{1. 試料}

テオフィリン徐放性製剤として，テオドール錠 100mg (TD, Lot. DH2, DH4, 日研化学社), テオロング錠 $100 \mathrm{mg}$ (TL, Lot. 2404, 2409, エ 一ザイ社）およびスロービッド $100 \mathrm{mg}$ カプセル (SB, Lot. CL074, SU065, 日本アップジョン社) を用いた。テオフィリンは試薬特級品(シグマ社) を使用した。メタノールは高速液体クロマトグラ フ用を, その他の試薬類は市販試薬（和光純薬） 特級品を用いた.

\section{2. 製剤の特性值}

製剤の特性值として重量, 硬度, 成分含量を選 択した。各特性值は， 2 種のロットについて測定 した。

（1）重量 各製剤について20個を無作為に選 択し, その重量を測定した。

（2）硬度 錠剂である TD および TL 各々 10個について木屋式硬度計を用いてその硬度を測 定した。

（3）成分含量 各製剂をめのう乳鉢を用いて 粉粋後, 遠沈管に入れメタノール $50 \mathrm{ml}$ を加えた 後, Handy Sonic UR-20P (トミ一精工) を用 いて 5 分間超音波処理した。ささらに精製水で50倍 希釈した後, 孔径 $0.22 \mu \mathrm{m}$ のメンブランフィルタ 一（ミリポア社）でろ過したものを試料とした. 試料中のテオフィリン量は, 高速液体クロマトグ ラフィー（HPLC 法）により測定し，あらかじめ 作成した検量線より製剤中の含有量を求めた。
HPLC 法の測定条件は, 装置として Waters LC Module I, 検出器; Waters $484(271 \mathrm{~nm})$, カラ ム; $\mu$ Bondapack C18 $(3.9 \times 300 \mathrm{~mm})$, カラム 温度; $40^{\circ} \mathrm{C}$, 移動相; メタノール/水 $(2 / 3)$, 流 速 $; 1 \mathrm{ml} / \mathrm{min}$, 注入量; $10 \mu \mathrm{l}$ とした。 また, 内部 標準物質としてカフェインを用いた。

\section{3. 放出特性}

各製剤の放出試験は，2 種類のロットについて 日局12溶出試験法（回転バスケット法）に準じて 液温 $37.0 \pm 0.5^{\circ} \mathrm{C}$, 回転数 $100 \mathrm{rpm}$ で行った. 試 験液は試験開始後 2 時間までは日局 12 崩壊試験法 第 1 液, 以後 24 時間までは第 2 液として経時的に $5 \mathrm{ml}$ を採取し，同量を補充した。試験液中のテォ フィリン含有量は前述の方法にしたがい HPLC 法により測定した.

\section{4. 保存安定性試験}

Fig. 1に示すように, 保存条件として温度を20 $\sim 80^{\circ} \mathrm{C}$ ，相対湿度を $40 \sim 70 \%$ の範囲で同時に変 化させた実験計画を作成した，製剤をナガノ社製 恒温恒湿器に14日間放置し, 経日的に前述の特性 值を測定した。保存14日後に括ける製剂の放出性 を前述の方法にしたがい観察した. 各試験の実施 にあたり, 試料数は 3 個とし, その平均值を求め た.

\section{5. 製戍の電子顕微鏡による観察}

製剂の保存後における構造的变化の有無を走査 型電子顕微鏡を用いて観察した.

\section{結果および考察}

製剂の特性值である重量, 硬度, 成分含量, おo

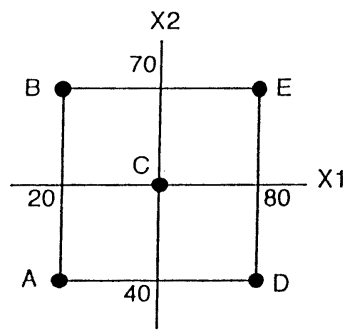

\begin{tabular}{|c|c|c|}
\hline & $\begin{array}{c}\mathrm{X} 1 \\
\text { Temp. }\left({ }^{\circ} \mathrm{C}\right)\end{array}$ & $\begin{array}{c}\text { X2 } \\
\text { R.H.(\%) }\end{array}$ \\
\hline A & 20 & 40 \\
\hline$B$ & 20 & 70 \\
\hline C & 50 & 55 \\
\hline $\mathrm{D}$ & 80 & 40 \\
\hline $\mathrm{E}$ & 80 & 70 \\
\hline
\end{tabular}

Fig. 1. Experimental Design of Two Factors and Physical Units $\mathrm{X} 1$ : temperature $\left(^{\circ}\right), \mathrm{X} 2$ : relative humidity (\%) 
よび溶出性についてロット間の差は認められず, ばらつきは小さかった（Table 1).

また，製凧の放出曲線と放出速度の時間的推移 をみると，TL と SB は剂形が異なるが， Fig. 2 のように放出挙動は極めて類似し, 約 7 時間で 80 \%が放出された。一方, TD は $80 \%$ 放出される のに約16時間を要した．TD の放出速度は，初期 において速く，2 時間以降は一定の值を示した.

これは, TD の構造が徐放性顆粒と速放性顆粒か らなる錠剂4,5)であることから,初期に拈ける放出 挙動は速放性顆粒によるものであり，その後徐放 性顆粒からテォフィリンを0次放出したものと考 える。

一方，TL と SB に抢いては，放出速度は時間 の経過とともに低下する傾向を示し，1 次放出を
示すことが観察されたＴL が徐放性顆粒と賦形 剂で構成されている4,6) ことから, 試験開始後錠 剤が速やかに崩壊した後に主薬が徐放性顆粒から 放出されたものと考える.SBは, 透過性膜を用 いて主薬の放出を制御した徐放性顆粒を充填した カプセル剂7) であり，この顆粒から薬物が 1 次放 出したものと考える.モーメント解析 ${ }^{8)}$ を実施 し, TD, TL および SB の平均放出時間を算出 したところ，それぞれ 7.9, 4.3，4.3 時間となり， TD は TLおよびSB の約 2 倍の值を示した。 た, 放出挙動を対数確率分布関数にあてはめて得 られた TD, TL 预よび SB の16\%放出時間値は, それぞれ 0.9，0.7，0.7 時間であったが，50\%放 出時間值はそれぞれ 4.5，2.3，2.7 時間であっ た. 一方, $84 \%$ 放出時間值は，それぞれ 22.1 ,

Table 1. Characteristics of Commercial Theophylline Preparations

\begin{tabular}{|c|c|c|c|c|}
\hline & & Weight (g) & Hardness $(\mathrm{kg})$ & Theophylline (mg) \\
\hline \multicolumn{2}{|c|}{ Sample No. } & 20 & 10 & 5 \\
\hline \multirow[t]{2}{*}{ TD } & $\operatorname{lot} A$ & $0.2991 \pm 0.0081$ & $3.42 \pm 0.50$ & $100.3 \pm 1.2$ \\
\hline & $\operatorname{lot} B$ & $0.2980 \pm 0.0081$ & $3.32 \pm 0.55$ & $103.8 \pm 2.9$ \\
\hline \multirow[t]{2}{*}{ TL } & $\operatorname{lot} A$ & $0.2357 \pm 0.0020$ & $4.24 \pm 0.60$ & 99.1 上3.0 \\
\hline & $\operatorname{lot} B$ & $0.2327 \pm 0.0014$ & $4.42 \pm 0.50$ & $102.4 \pm 0.9$ \\
\hline \multirow[t]{2}{*}{$\mathrm{SB}$} & $\operatorname{lot} \Lambda$ & $0.2598 \pm 0.0028$ & - & 97.5 上 2.2 \\
\hline & $\operatorname{lot} \mathrm{B}$ & $0.2589 \pm 0.0037$ & - & $98.1 \pm 2.5$ \\
\hline
\end{tabular}

TD: Theodur, TL: Theolong, SB: Slo-bid

Each data represents the mean \pm S.D.
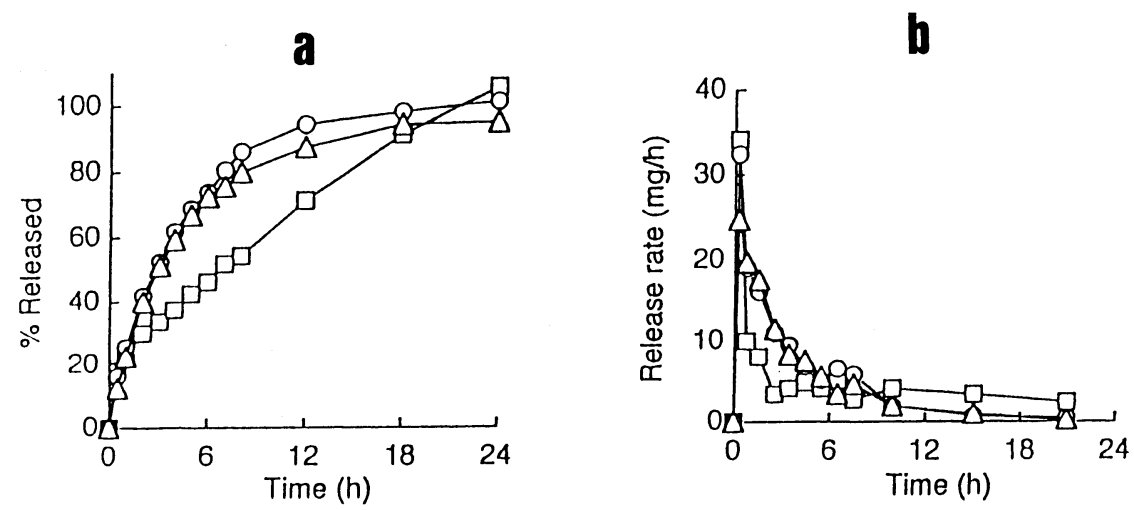

Fig. 2. Time Course of Theophyline Release (a) and Release Rate (b) of Commercial Preparations

$\square$ : Theodur, $\bigcirc$ : Theolong, $\triangle$ : Slo-bid

Each point represents the mean \pm S.D. $(n=3)$. 
7.7，9.9時間と TD が TL および SB の 2 倍以上 であり，放出が遅いことが示された。

各製剂の保存安定性については，保存14日後の 重量が， $80^{\circ} \mathrm{C}-70 \%$ に怙いて約 10\% 増加したが 他の保存条件ではほとんど変化はみられなかっ た. 各保存条件における TD および TL の硬度 の時間的変化を Fig. 3 に示すが，TDは $80^{\circ} \mathrm{C}$ $70 \%$ で急激に低下し，測定不能となった。ささらに $80^{\circ} \mathrm{C}-40 \%, 50^{\circ} \mathrm{C}-55 \%$ 条件下に打いても TD の硬度は低下した.TL の硬度については, $80^{\circ} \mathrm{C}-70 \%$ の条件下で徐々に低下し，14日後に 測定不可能となった．14日後における硬度の予測 のため重回㷌分析を実施し，得られた予測式を 3 次元図にあらわした (Fig. 4). TD の硬度は温 度と湿度の両条件の影響を受け，高温多湿になる ほど低下する傾向が示された。
TD

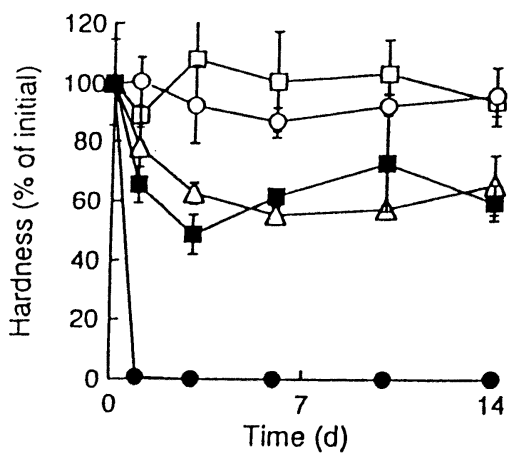

TL

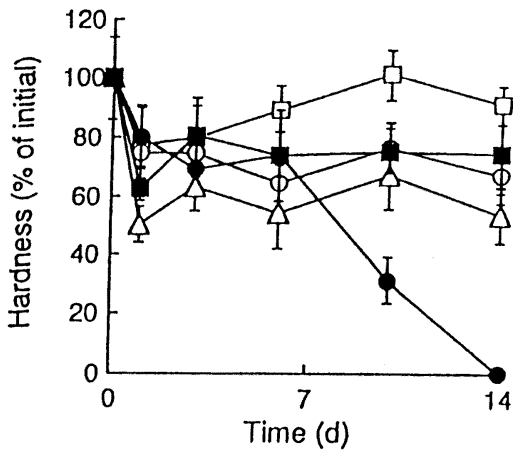

Fig. 3. Effect of Storage Conditions on Hardness of Preparations TD : Theodur, TL : Theolong

$\square: 20^{\circ}-40 \%, \quad \circ: 20^{\circ}-70 \%, \triangle: 50^{\circ}-55 \%, \square: 80^{\circ}-40 \%$,

- : $80^{\circ} 70 \%$

Each point represents the mean \pm S.D. $(n=3)$.

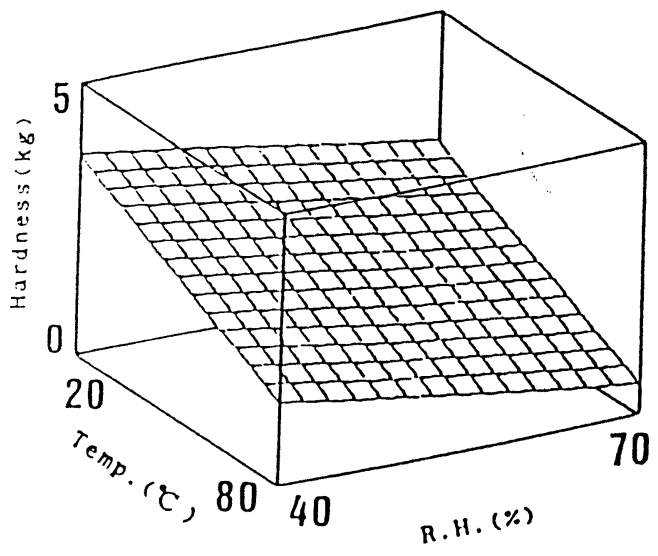

TD

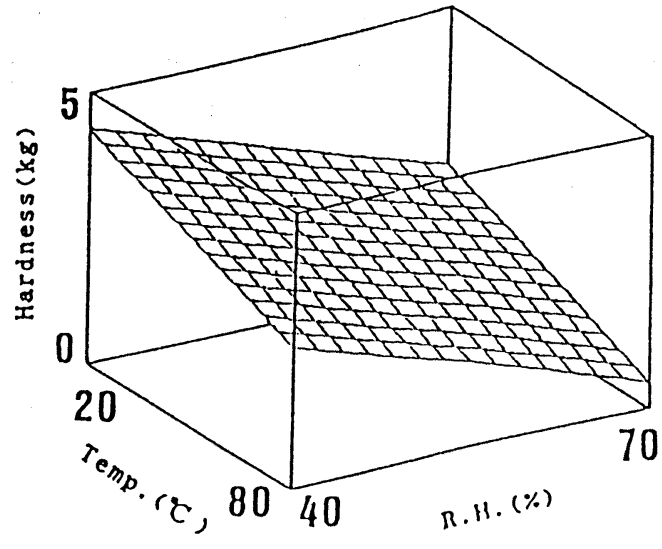

TL

Fig. 4. Three Demensional Plots of Hardness of Theophylline Tablets against Temperature and Relative Humidity for Storage (14 days) TD : Theodur, TL : Theolong 
製剤の主薬含有量については, 保存条件によら ず安定であった，保存14日後に和壮る各製剤につ いて放出試験を施行した。 TDの放出举動（Fig. 5）を保存前と比較すると，20 $\mathrm{C}-40,20^{\circ} \mathrm{C}$ $70 \%$ 拈よび $50{ }^{\circ} \mathrm{C}-55 \%$ の条件に打いては大きな 変化は認められなかった。しかし, $80^{\circ} \mathrm{C}-40 \%$ 打 よび $80^{\circ} \mathrm{C}-70 \%$ では放出は速くなる傾向が観察 され, 約 8 時間で $80 \%$ 以上が放出され, MDT 值 もまた約 2 分の 1 亿短縮された。 その放出速度

a

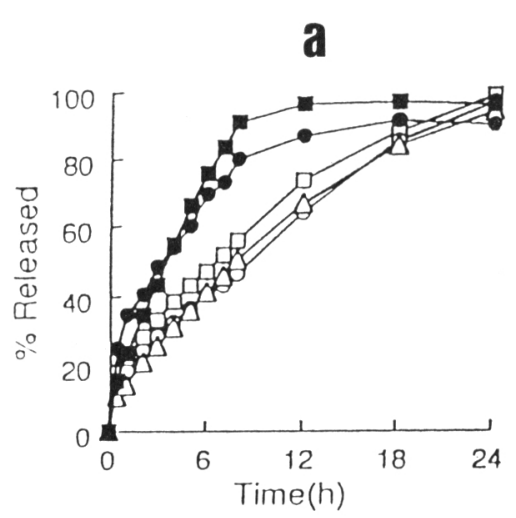

は, 保存前では 1 時間以降約 $5 \mathrm{mg} / \mathrm{h}$ でほほ定 であったのにたいして，過酷な条件である $80^{\circ} \mathrm{C}$ -40\%抢よび $80^{\circ} \mathrm{C}-70 \%$ では約 $10 \mathrm{mg} / \mathrm{h}$ へと増 加した。保存前之 $80^{\circ} \mathrm{C}$ の高温保存（14日）に揖 汀る顆粒表面の状態を走查型電子顕微鏡によって 観察したところ表面構造に熱の影響を示唆する変 化がみられた（Fig，6）。以上の結果より，製剂 の高温保存により, 顆粒の構造変化が括こり, 主 薬の放出が早まったものと推定している.

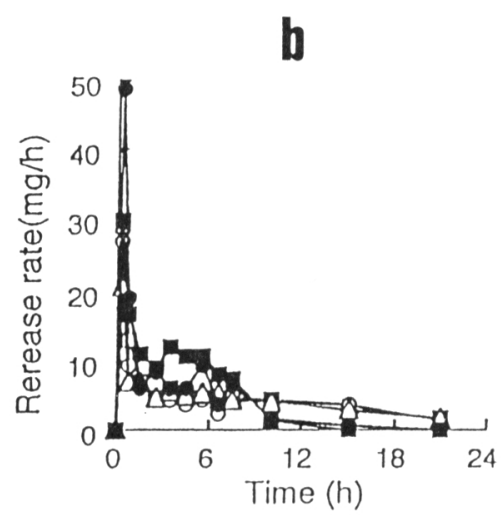

Fig. 5. Release Profiles of Theophylline from Theodur Stored under Different Conditions (14 days)

$\mathrm{a}: \%$ released, $\mathrm{b}:$ release rate
$\square: 20^{\circ}-40 \%, \bigcirc: 20^{\circ}-70 \%, \triangle: 50^{\circ}-55 \%$,
$: 80^{\circ}-40 \%$,
- : $80^{\circ}-70 \%$
Each point represents the mean \pm S.D. $(n=3)$.

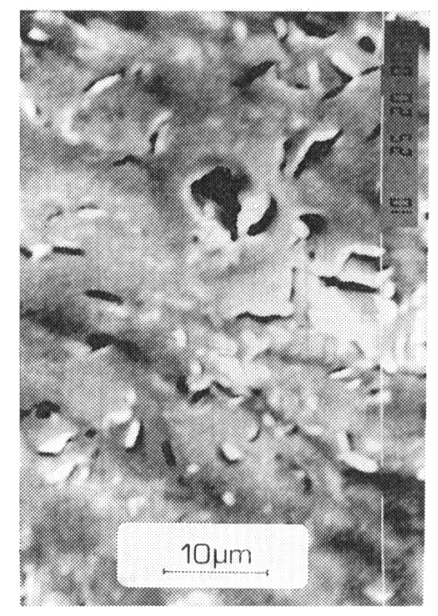

(a)

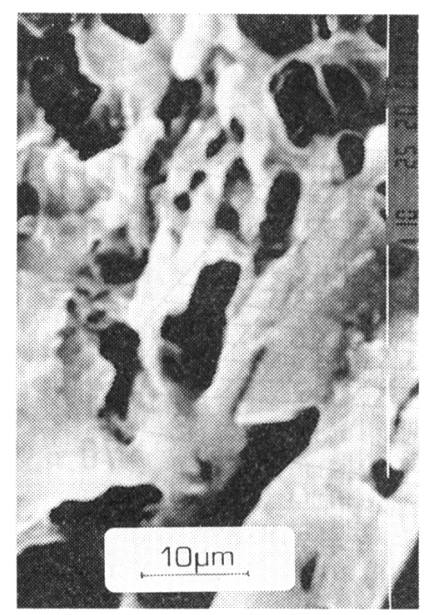

(b)

Fig. 6 Scanning Electron Micrographs of Theodur before (a) and after Storage in $80^{\circ} \mathrm{C}$ for 14 days (b) 
TL の放出挙動 (Fig. 7) については $80^{\circ} \mathrm{C}$ の 保存条件泟いて，他の保存条件之異なる放出挙 動を示し，初期比和壮る放出速度は遅くなった。 MDT 值を比較すると, $80^{\circ} \mathrm{C}-40 \%$ および $80^{\circ} \mathrm{C}$ -70\% 保存条件では他の保存条件に比べて約 1.5 倍になった，TLの徐放性顆粒についても走查電 子顕微鏡によって表面構造を観察したところFig. 8 のように保存 14 日後の顆粒の表面構造に変化が

a

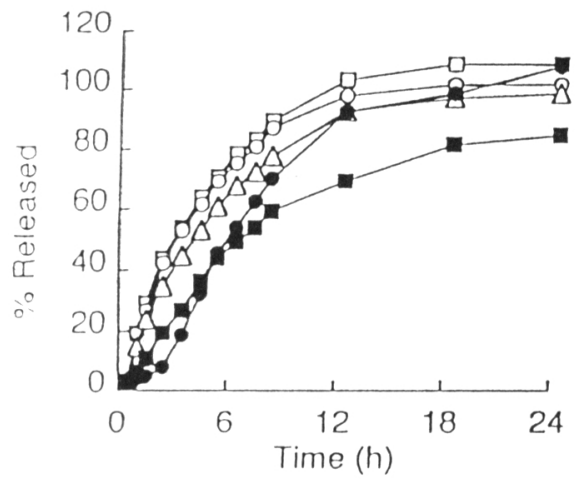

観察された。ワックスマトリクス製剤において は, 高温保存により多形現象がみられ, 放出挙動 の変化が報告されており拈， その際同時に表面形 態も変化するとされている。したがって，TLの 場合も末たワックスの融解之之もに多形現象が生 じたことも予想され，今後さらに検討すべき課題 であると考苀る。

$\mathrm{SB}$ の放出举動には, 保存前に比べていずれも

Fig. 7. Release Profiles of Theophylline from Theolong Stored under Different Conditions (14 days) $\mathrm{a}: \%$ released, b : release rate $\square: 20^{\circ}-40 \%, \circ: 20^{\circ}-70 \%, \triangle: 50^{\circ}-55 \%$, : $80^{\circ}-40 \%, \quad: 80^{\circ}-70 \%$ Each point represents the mean \pm S.D. $(n=3)$.

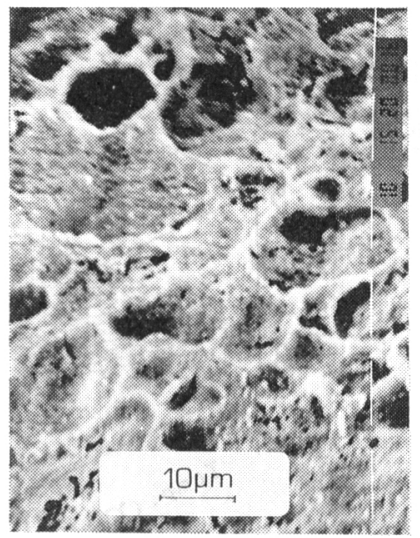

(a )

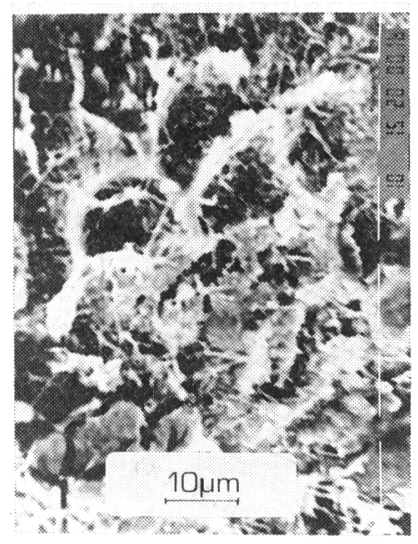

( b )

Fig. 8. Scanning Electron Micrographs of Theolong before (a) and after Storage in $80^{\circ} \mathrm{C}$ for 14 days (b) 
a

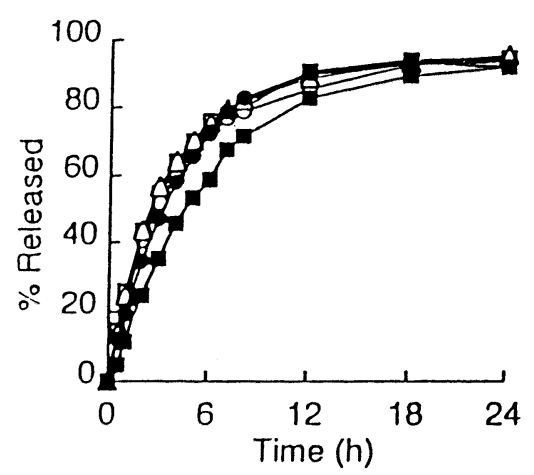

b

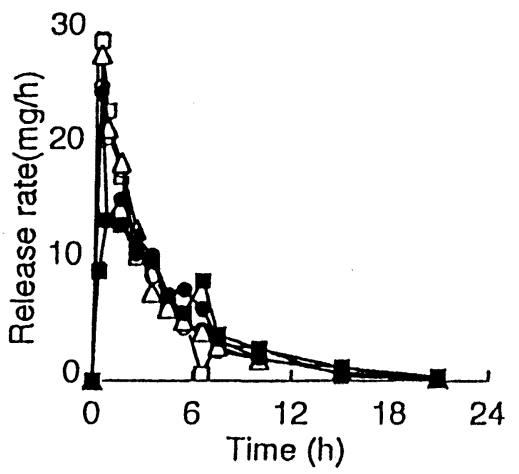

Fig. 9. Release Profiles of Theophylline fron Slo-bid Stored under Different Conditions (14 days)

$\mathrm{a}: \%$ released, $\mathrm{b}:$ release rate

$\square: 20^{\circ}-40 \%, \circ: 20^{\circ}-70 \%, \triangle: 50^{\circ}-55 \%, \square: 80^{\circ}-40 \%, \bullet: 80^{\circ}-70 \%$

Each point represents the mean \pm S.D. $(n=3)$.

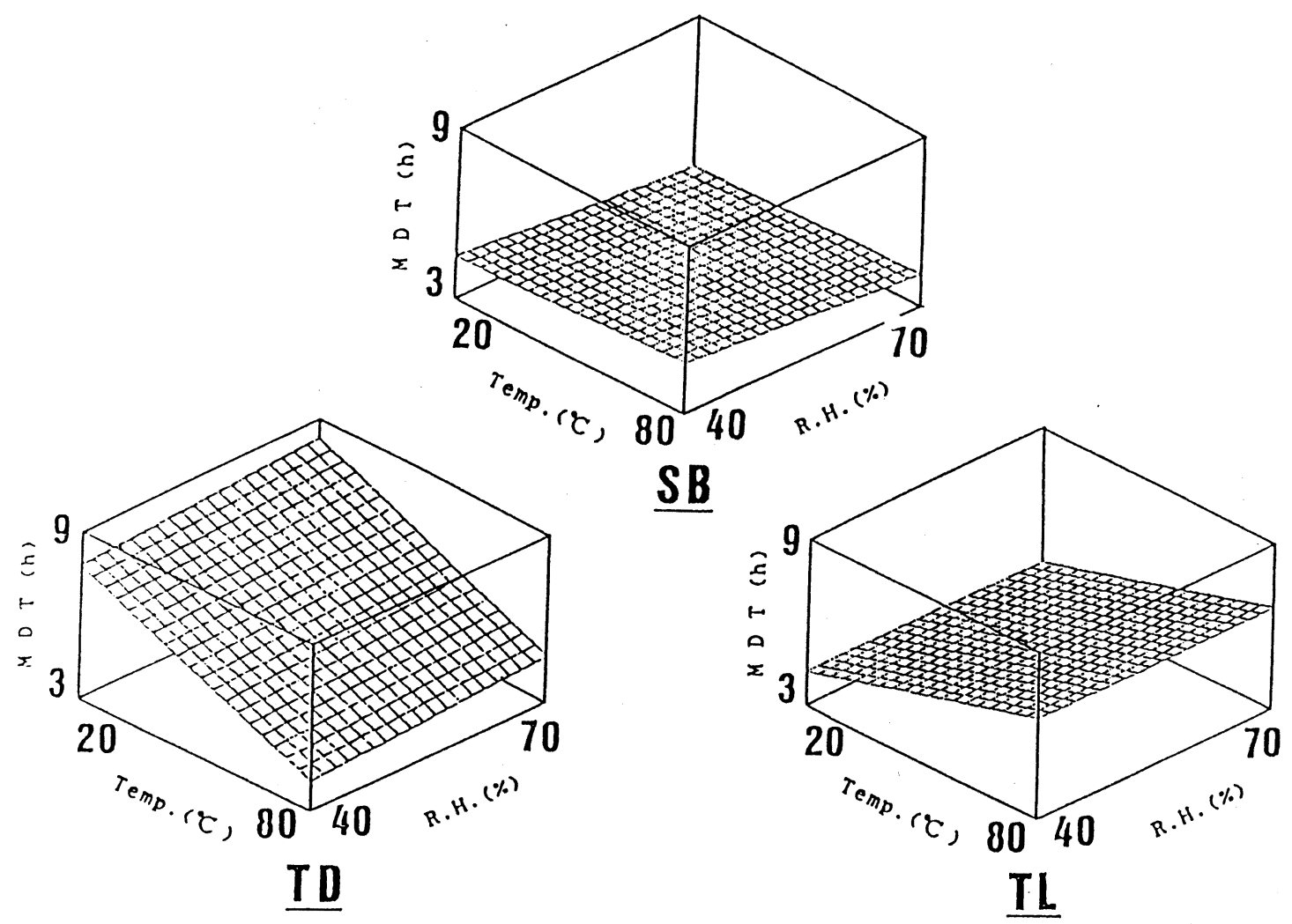

Fig. 10. Three Dimensional Plots of MDT of Theophylline Preparations against Storage Temperature (Temp.) and Relative Humidity (R.H.)

TD : Theodur, TL : Theolong, SB : Slo-bid 
大きな変化は観察されなかった（Fig. 9). また， SB 中の顆粒のみについて $80^{\circ} \mathrm{C}-70 \%$ で14日間 保存してその放出性を観察したところ，大きな変 化は観察されなかった。したがって, SB の顆粒 自体が保存温度, 保存湿度の環境変化にたいして 安定な製剂であることが確認された。

保存14日後の溶出試験の結果より得られた MD $\mathrm{T}$ 值について, 重回帰分析を実施して得られた, 温度および湿度よりMDT 值を予測するための式 を 3 次元図であらわした（Fig，10). TD および TL では, 湿度の影響は少なく, 温度の影響をよ り大きく受けることが示された，TDでは, 温度 の上昇にともない溶出が早まり，TL では遅くな る傾向がみられた。一方, SB では温度, 湿度の 影響はみられなかった。

薬物治療に乱いて, 製剤の市販後の保存環境と 製剂特性の変化との関係を捉えることは重要であ り, 特に徐放性製剤の溶出過程は薬効の確保にお いて重要な要因となる.

本研究によっても, 同じテオフィリン製剤であ っても，それらの製剤技術の違いによって薬剤特 性に差が生じるだけでなく，その保存環境下にお ける薬剤の安定性においても大きな相違が存在す ることが判明した。したがって，薬剤の選択にあ
たっては，薬剤師としての薬学的観点からのデー タ提供が, 薬物の適正使用の推進にとって重要で あると考えられる。

謝辟 本研究にあたり，ご指導ご協力いただきまし た星薬科大学薬剂学教室, 永井恒司教授, ならびに同 教室諸氏に深謝いたします。

\section{引用文 献}

1) 高木健三, カレントテラピー,13，117-123(1995).

2）石崎高志, “TDMの基礎 Pharmacokinetics 理論 をもとにして, 喘息の薬物治療法予防的治療法”, 長野準他編, メディカルトリビューン, 1989, pp. 18-39.

3) K. Takayama and T. Nagai, Chem. Pharm. Bull., 37, 160-167 (1989).

4) 堀了平, “図解 夢の DDS”, 薬業時報社, 東 京, 1991, pp.15.

5) テオドールインタビューフォーム, 日研化学(秼)

6) テオロングインタビューフォーム，エーザイ侏

7）スロービッドインタビューフォーム, 日本アップ ジョン(秼

8）山岡 清, “マイコンによる薬物体内動態解析 法”, 南江堂, 東京, 1984, pp.145-184.

9) Y. Akiyama, M. Yoshioka, H. Horibe, S. Hirai, N. Kitamori and H. Toguchi, J. Cont. Release, 26, 1-10 (1993). 